\title{
REKAMAN ELEKRONIK PERSONAL CHAT PADA SOCIAL MEDIA SEBAGAI ALAT BUKTI
}

\author{
I Putu Krisna Adhi \\ putukrisnaadhi@gmail.com \\ Universitas Airlangga
}

\begin{abstract}
This journal is titled "Personal Chat Electronic Record on Social Media as a Proof Tool". The problem formulation of this journal contains how a Personal Chat can be used as a legitimate evidence in front of the court seen from Indonesia's positive law and also the comparison of some personal chat features on some social media that can be used as valid evidence in court. This writing uses a normative legal research method by linking various sources related to the validity of the Personal Chat as a valid proof. The reason for using normative due to the obscurity of norms in national rules regarding the verification of Personal Chat in court. The conclusion of this journal is in accordance with the Republic of Indonesia Number 19 of 2016 concerning Amendments to Law Number 11 of 2008 concerning Information and Electronic Transactions which will then be referred to as the ITE Law, Electronic Information and / or Electronic Documents and / or results the print is a valid legal proof, and this Personal Chat is a proof of evidence that the Personal Chat as a proof cannot stand alone. The requirement for Personal Chat to become evidence in the trial is that it has fulfilled the formal and material requirements, accompanied by expert information or digital forensics, fulfills the verification of authentication and also the necessity of merging with other evidence as a provision for the minimum principle of evidence. Regarding the use of personal chat as a legitimate means of proof it is also not immediately obtained from various social media, but from several social media applications that have fulfilled the standardization of authenticity and security guarantees. Keywords: Electronic Recordings; Personal Chat; Social Media; Digital Evidence.
\end{abstract}

\begin{abstract}
Abstrak
Jurnal ini berjudul "Rekaman Elektronik Personal Chat Pada Social Media Sebagai Alat Bukti". Rumusan masalah jurnal ini berisikan tentang bagaimana suatu Personal Chat tersebut dapat dijadikan sebagai alat bukti yang sah dimuka pengadilan dilihat dari hukum positif Indonesia dan juga komparasi dari beberapa fitur personal chat pada beberapa social media yang dapat dijadikan alat bukti yang sah dimuka persidangan. Penulisan ini menggunakan metode penelitian hukum normatif dengan mengaitkan berbagai sumber yang berkaitan dengan keabsahan Personal Chat tersebut sebagai alat bukti yang sah. Alasan mempergunakan normatif dikarenakan kekaburan norma dalam aturan nasional mengenai pembuktian Personal Chat di dalam pengadilan. Kesimpulan dari jurnal ini yaitu sesuai dengan -Undang Republik Indonesia Nomor 19 Tahun 2016 Tentang Perubahan Atas Undang-Undang Nomor 11 Tahun 2008 Tentang Informasi Dan Transaksi Elektronik yang selanjutnya akan disebut Undang-Undang ITE, Informasi Elektronik dan/atau Dokumen Elektronik dan/atau hasil cetaknya merupakan alat bukti hukum yang sah, serta Personal Chat ini sebagai alat bukti petunjuk dimana Personal Chat sebagai alat bukti tidak dapat berdiri sendiri. Syarat agar Personal Chat menjadi alat bukti dalam persidangan adalah telah memenuhi syarat formil dan materiil, disertai oleh keterangan ahli atau digital forensik, memenuhi kasifikasi otentifikasi dan juga keharusan penggabungan dengan alat bukti lain sebagai sebuah ketentuan adanya prinsip minimum alat bukti. Mengenai penggunaan personal chat sebagai alat bukti yang sah juga tidak serta-merta didapat dari berbagai social media akan tetapi dari beberapa aplikasi social media yang sudah memenuhi standarisasi otentisitas dan jaminan keamanan.
\end{abstract}

Kata Kunci: Rekaman Elektronik; Personal Chat; Social Media; Alat Bukti. 


\section{Pendahuluan}

Dewasa ini, pada era milenia yang telah sangat maju baik perkembangan disektor perekonomian, industri maupun teknologi berjalan sangatlah pesat, oleh karenanya berdampak besar pada perkembangan sistem informasi dan juga elektronik. Sistem elektronik dipergunakan sebagai media dari keberadaan sistem informasi yang merupakan penerapan teknologi informasi yang berbasis telekomunikasi dan media elektronik yang berfungsi memproses menganalisa, menampilkan, dan mengirimkan atau menyebarkan informasi elektronik. ${ }^{1}$ Sesuai perkembangan tersebut, maka berkembang pula modus-modus kejahatan di Indonesia yang merupakan suatu tindakan pidana. Salah satunya kejahatan melalui mobile phone atau handphone yang berbasis online. Dengan perkembangan teknologi kini sudah hampir semua pihak dan dari berbagai kalangan usia secara tidak langsung melakukan interkaksi berbasis online. Saat ini handphone memiliki banyak kelebihan serta fitur-fitur yang menarik yang ditawarkan didalamnya dan yang sangat digemari diantara fitur-fitur tersebut ialah aplikasi komunikasi dan kehidupan dunia maya atau online yaitu social media. Aplikasi ini mampu menyediakan ruang komunikasi kepada siapa saja dan kapan saja tanpa harus mengeluarkan biaya maupun pulsa dan tentunya dengan waktu yang sangat singkat dan praktis. Fitur pada social media tersebut ialah personal chat. Personal chat pada suatu social media juga dapat menjadi sarana dalam melakukan suatu kejahatan. Kecenderungan yang terdapat pada personal Chat dapat memunculkan modusmodus baru dalam bidang kejahatan, diantaranya guna mendukung berbagai tindak kejahatan yang dilakukan, baik secara sengaja dan terang-terangan maupun tidak sengaja. Contoh yang dapat dilihat adanya beberapa tindakan yang menggunakan personal chat pada social media sebagai sarana ialah defamation (pencemaran nama baik), penodaan/penistaan agama seperti pada kasus yang menjerat mantan gubernur Jakarta sodara Basuki Tjahaja Purnama dan Ahmad Dhani, kasus peronal chat sodara Rizieq Shihab, ancaman online, penipuan online dan masih banyak modus-

1 Siswanto Sunarso, Hukum Informasi dan Transaksi Elektronik (Rineka Cipta 2009).[42]. 
modus kejahatan berbasis online yang tentunya memberikan keleluasaan kepada pihak-pihak yang berniat menyalahgunakan sarana personal chat pada social media ini. Perkembangan kriminalitas atau tindak pidana dalam masyarakat yang sedang mengalami modernisasi meliputi masalah-masalah yang berhubungan dengan frekuensi kejahatan, kualitas kejahatan, perubahan unsur-unsur perbuatannya dan kemungkinan timbulnya jenis-jenis kejahatan atau tindak pidana baru. ${ }^{2}$

Efek globalisasi yang mempengaruhi timbulnya tindak pidana ini mau tak mau memberikan dampak bagi tatanan hukum yang berlaku di Indonesia. Kemudian penggunaan Personal Chat dalam sarana pendukung tindak kejahatan akan berhadapan dengan keabsahannya sebagai alat bukti yang sah dalam persidangan. Pemerintah telah memberikan respon positif terhadap perkembangan globalisasi ini, ditandai dengan lahirnya Undang-Undang Negara Republik Indonesia Nomor 11 tahun 2008 juncto Nomor 19 Tahun 2016 Tentang Informasi dan Transaksi Elektronik yang lebih dikenal dengan UU ITE. Pada saat ini, UU ITE sudah mampu mengakomodir tentang alat bukti elektronik. Namun, dalam perkara pidana bahasannya masih terbatas. Maka dari itu perlu diadakannya kajian yuridis mengenai rekaman elektronik Personal Chat tersebut sebagai alat bukti yang sah sesuai dengan hukum postif Indonesia.

\section{Rumusan Masalah}

Berdasarkan atas latar belakang tersebut di atas maka dapat dirumuskan permasalahan sebagai berikut yaitu:

1. Personal chat pada social media sebagai alat bukti pada hukum acara pidana di Indonesia.

2. Komparasi personal chat pada social media sebagai alat bukti.

\section{Tipe Penelitian}

Penelitian pada jurnal ini mempergunakan metode penelitian hukum

2 Muladi \& Barda Nawawie Arief, Teori - teori dan Kebijakan Pidana (Alumni 2008).[86]. 
normatif, yaitu suatu penelitian hukum doktrinal. Penelitian hukum doktrinal adalah penelitian-penelitian atas hukum yang dikonsepkan dan dikembangkan atas dasar doktrin yang dianut sang pengkonsep dan atau sang pengembangnya. Ada berbagai doktrin yang pernah dianut dan dikembangkan dalam kajian-kajian hukum, mulai dari doktrin klasik - yang dikenali sebagai doktrin (atau aliran) hukum alam kaum filosof dan doktrin (atau aliran) positifisme para yuris-legis sampai ke doktrin historis dan doktrin realisme-fungsionalisme para ahli hukum yang terbilang kaum realis. Berikut ini akan dipaparkan berturut-turut metode doktrinal yang dikenal dalam aliran hukum alam, metode doktrinal yang dianut kaum positivis (yang juga disebut kaum legis itu), dan kemudian juga metode doktrinal yang ditradisikan di kalangan para ahli hukum yang berpaham fungsionalis-realisme. Selain itu juga sebagai penelitian perpustakaan atau studi dokumen. Disebut penelitian hukum doktrinal, karena penelitian ini dilakukan atau ditujukan hanya pada peraturan peraturan yang tertulis atau bahan - bahan hukum yang lain.

\section{Pendekatan Masalah}

Penelitian ini menggunakan 3 (tiga) jenis pendekatan masalah dalam membedah permasalahan penelitian yaitu pendekatan perundang-undangan (statue approach), pendekatan konseptual (conceptual approach) dan pendekatan perbandingan (comparative approach). Adapun arti jenis pendekatan dimaksud adalah:

a. Pendekatan perundang-undangan (statue approach) digunakan untuk meneliti pengaturan mengenai sistem peradilan dan peraturan perundang-undangan mengenai alat bukti, dari peraturan tersebut dapat dicermati rumusan normanya sebagai suatu identifikasi sumber hukum yang dijadikan dasar pemecahan permasalahan penelitian.

b. Pendekatan konseptual (conceptual approach), pendekatan ini beranjak dari pandangan-pandangan dan doktrin-doktrin yang berkembang di dalam ilmu hukum. Pendekatan konseptual (conceptual approach) digunakan untuk mengkaji suatu rekaman elektronik personal chat tersebut sebagai alat bukti dalam suatu kasus hukum di Indonesia. 
c. Pendekatan perbandingan (comparative approach) digunakan untuk membandingkan antara konsep rekaman elektronik yang secara mengkhusus pada personal chat pada beberapa jenis social media sebagai pembanding, dari karakteristik masing-masing personal chat pada beberapa contoh social media yang diperbandingkan menjadi suatu alat bukti.

\section{Sumber Bahan Hukum}

Bahan hukum yang dipergunakan dalam penelitian ini adalah bahan hukum primer dan bahan hukum sekunder. Bahan hukum dimaksud dapat dijelaskan sebagai berikut:

\section{a. Bahan hukum primer}

Bahan hukum primer, yaitu bahan-bahan hukum yang mengikat yang berupa peraturan perundang-undangan yang berkaitan dengan rekaman elektronik sebagai alat bukti mengkhusus pada jenis personal chat pada social media. Bahan Hukum Utama yang berkaitan dengan permasalahan yang penulis bahas dan menjadi bahan hukum primer adalah Undang-Undang Dasar Negara Republik Indonesia Tahun 1945, Undang-Undang Nomor 11 tahun 2008 jo Undang-Undang Nomor 19 tahun 2016 Tentang Informasi dan Transaksi Elektronik, Peraturan Pemerintah Republik Indonesia Nomor 82 Tahun 2012 Tentang Penyelenggaraan Sistem dan Transaksi

Elektronik, Permenkominfo Republik Indonesia Nomor 7 Tahun 2016 Tentang Administrasi Penyidikan dan Penindakan Tindak Pidana di Bidang Teknologi Informasi dan Transaksi Elektronik.

\section{b. Bahan hukum sekunder}

Bahan hukum sekunder adalah bahan hukum yang memberikan penjelasan terhadap bahan hukum primer, yaitu meliputi buku, artikel, jurnal dan bahan-bahan hukum tertulis lainnya yang berhubungan dengan permasalahan penelitian.

\section{Metode Pengumpulan Bahan Hukum}

Teknik pengumpulan bahan hukum dilakukan melalui studi dokumen, yaitu dilakukan dengan pengumpulan data dengan jalam mencatat bahan - bahan 
hukum hukum yang relevan dengan permasalahan penelitian, baik primer maupun sekunder yang berkaitan dengan permasalahan penelitian. Sebelum pencatatan, dilakukan langkah-langkah interventarisasi dan klasifikasi bahan-bahan hukum yang dibutuhkan.

\section{Analisis Bahan Hukum}

Dalam menganalisis bahan - bahan hukum yang telah terkumpul, maka dapat digunakan teknik analisis seperti: deskripsi, interpretasi, konstruksi, evaluasi, argumentasi, dan sistematisasi. Teknik analisis bahan hukum yang digunakan dalam penelitian ini adalah teknik deskripsi, interpretasi dan sistematisasi yang diuraikan sebagai berikut:

1. Teknik deskripsi adalah teknik dasar analisis yang tidak dapat dihindari penggunaannya. Deskripsi berarti uraian apa adanya terhadap suatu kondisi atau posisi dari proposisi-proposisi hukum atau non hukum.

2. Teknik interpretasi berupa penggunaan jenis- jenis penafsiran dalam ilmu hukum seperti penafsiran gramatikal, historis, sistematis, teleologis, konseptual, dan penafsiran lainnya.

3. Teknik sistematisasi adalah berupa upaya mencari kaitan rumusan suatu konsep hukum atau proposisi hukum antara peraturan perundangundangan yang sederajat maupun antara yang tidak sederajat.

\section{Sistimatika Penulisan}

Dalam penulisan jurnal ini penulis menggunakan beberapa asas dan teori sebagai konsep untuk menjawab permasalahan pertama dan kedua sehingga dari konsep tersebut penulis dapat memperoleh hipotesis atas permasalahan penelitian. Terhadap hal tersebut dijabarkan sebagai berikut;

Sebagaimana dikatakan dalam Pasal 5 ayat Undang-Undang No. 11 Tahun 2008 tentang Informasi dan Transaksi Elektronik Informasi Elektronik dan/atau Dokumen Elektronik dan/atau hasil cetaknya merupakan alat bukti hukum yang sah..

Syarat agar Personal Chat pada Social Media tersebut dapat menjadi alat bukti dalam persidangan adalah juga keharusan penggabungan dengan alat bukti 
lain sebagai sebuah ketentuan adanya prinsip minimum alat bukti (Pasal 183 KUHAP). Penggunaan Personal Chat pada Social Media sebagai alat bukti akan lebih valid lagi apabila digunakan untuk tindak pidana khusus yang memberikan pelegalan penggunaan alat bukti elektronik dalam pasalnya.

Syarat formil diatur dalam Pasal 5 ayat (4) UU ITE, yaitu bahwa Informasi atau Dokumen Elektronik bukanlah dokumen atau surat yang menurut perundang-undangan harus dalam bentuk tertulis. Sedangkan syarat materil diatur dalam Pasal 6, Pasal 15, dan Pasal 16 UU ITE, yang pada intinya Informasi dan Dokumen Elektronik harus dapat dijamin keotentikannya, keutuhannya, dan ketersediaanya. Untuk menjamin terpenuhinya persyaratan materil yang dimaksud, dalam banyak hal dibutuhkan digital forensik.

Dengan demikian, email, file rekaman atas chatting, dan berbagai dokumen elektronik lainnya dapat digunakan sebagai alat bukti yang sah. Dalam beberapa putusan pengadilan, terdapat putusan-putusan yang membahas mengenai kedudukan dan pengakuan atas alat bukti elektronik yang disajikan dalam persidangan.

\section{Personal Chat pada Social Media sebagai alat bukti}

\section{a. Alat Bukti Rekaman Elektronik}

Dalam suatu perkara pidana, suatu "perbuatan pidana" merupakan kenyataan bahwa ada aturan yang melarang dan mengancam dengan pidana barang siapa yang melanggar larangan tersebut. ${ }^{3}$ Untuk menentukan adanya pertanggungjawaban pidana merupakan ranah dari hukum pidana formil yang berkaitan dengan hukum acara untuk memeriksa kesalahan dari si pembuat, yaitu si pembuat harus memenuhi seluruh seluruh unsur delik yang didakwakan dan terbukti sebagai pelakunya. Mengenai pengertian bukti dan alat bukti dapat disimak dari Subekti yang menyatakan bahwa bukti adalah sesuatu untuk meyakinkan akan kebenaran suatu dalil atau pendirian. Sedangkan alat bukti, alat pembuktian, upaya pembuktian adalah alat yang dipergunakan untuk membuktikan dalil-dalil suatu pihak di pengadilan. ${ }^{4}$

3 Roeslan Saleh, Perbuatan Pidana dan Pertanggungjawaban Pidana (PT Aksara Baru 1980).[14].

4 Subekti, Kamus Hukum (Pradnya Paramita 2003).[17]. 
Pembuktian dalam hukum acara pidana menjadi sesuatu yang esensial dalam suatu proses hukum di pengadilan. Dalam pembuktian ini sangatlah penting untuk mencari suatu kebenaran, yakni kebenaran materiil. Kebenaran materiil artinya kebenaran yang selengkap-lengkapnya dengan menerapkan ketentuan hukum dengan tepat yang bertujuan untuk mencari pelaku suatu tindak pidana. ${ }^{5}$ Untuk memperoleh kebenaran materiil dalam proses hukum atau persidangan maka diperlukan tahapan yang sistematis yang diatur dalam hukum pembuktian. Hukum pembuktian ialah seperangkat kaidah hukum yang mengatur tentang pembuktian, ${ }^{6}$ di Indonesia hukum pembuktian ini diatur dalam Undang-Undang Nomor 8 Tahun 1981 Tentang Hukum Acara Pidana. Sistem pembuktian yang dianut dalam KUHAP ialah diatur dalam Pasal 183 KUHAP, yang disebut: "Hakim tidak boleh menjatuhkan pidana kepada seseorang kecuali apabila dengan sekurang-kurangnya dua alat bukti yang sah ia memperoleh keyakinan bahwa suatu tindak pidana benarbenar terjadi dan bahwa terdakwalah yang bersalah melakukannya". ${ }^{7}$ Berdasakan Pasal 183 KUHAP tersebut, maka sistem pembuktian yang dianut oleh KUHAP ialah sistem pembuktian menurut undang-undang secara negatif yakni menggabungkan antara sistem pembuktian positif yang berpusat pada pembuktian melalui alatalat bukti dengan sistem pembuktian menurut keyakinan atau conviction-in time. ${ }^{8}$ Dalam pasal tersebut harus terpenuhi dua syarat mutlak, yakni (1) Alat bukti yang cukup; dan (2) Keyakinan hakim. ${ }^{9}$ Berdasarkan dua syarat tersebut dapat dikatakan bahwa sistem pembuktian ini dalam membentuk keyakinan hakim memiliki peran penting dari alat bukti dalam persidangan, maka hakim harus mencari kebenaran materiil dengan mencari fakta yang sebenarnya yang terungkap dalam persidangan, khususnya melalui alat bukti yang sah.

\footnotetext{
5 Jupri, 'Pengertian Hukum Acara Pidana' (negarahukum.com 26 Februari 2012) <www. negarahukum.com $>$ accessed 2 Juli 2018.

6 Munir Fuady, Teori Hukum Pembuktian: Pidana dan Perdata (PT. Citra Adiya Bakti 2012).[1].

7 M. Yahya Harahap, Pembahasan Permasalahan dan Penerapan KUHAP: Pemeriksaan Sidang Pengadilan, Banding, Kasasi dan Peninjauan Kembali (Sinar Grafika 2006).[280].

8 Ibid.

9 Munir Fuady, Op. Cit.[2].
} 
Alat bukti adalah alat-alat yang ada hubungannya dengan suatu tndakan pidana, dimana alat tersebut dapat dipergunakan sebagai bahan pembuktan, guna menimbulkan keyakinan bagi hakim atas kebenaran adanya suatu tindak pidana yang telah dilakukan oleh terdakwa. ${ }^{10}$ Alat bukti dapat didefinisikan juga sebagai segala hal yang dapat digunakan untuk membuktikan perihal kebenaran suatu peristiwa di pengadilan. ${ }^{11}$ Semua hal yang dapat dijadikan alat bukti tidaklah terbatas pada suatu benda, namun tidak semua juga dapat dihadirkan dipersidangan karena setiap hukum acara telah menentukan batasan dan kriteria alat bukti yang dianggap sah dimuka pengadilan. Selain itu, dalam hukum acara tertentu mengatur mengenai perluasan mengenai suatu alat bukti yang sah yang tentunya tidak keluar ataupun menyimpang dari ketentuan yang diatur dalam undang-undang khususnya dalam KUHAP.

Sesuai yang telah dijelaskan pada Pasal 1 Angka 4 Undang-Undang Republik Indonesia Nomor 19 Tahun 2016 Tentang Perubahan Atas Undang-Undang Nomor 11 Tahun 2008 Tentang Informasi Dan Transaksi Elektronik yang selanjutnya akan disebut Undang-Undang ITE. Dokumen Elektronik adalah setiap Informasi Elektronik yang dibuat, diteruskan, dikirimkan, diterima, atau disimpan dalam bentuk analog, digital, elektromagnetik, optikal, atau sejenisnya, yang dapat dilihat, ditampilkan, dan/atau didengar melalui Komputer atau Sistem Elektronik, termasuk tetapi tidak terbatas pada tulisan, suara, gambar, peta, rancangan, foto atau sejenisnya, huruf, tanda, angka, Kode Akses, simbol atau perforasi yang memiliki makna atau arti atau dapat dipahami oleh orang yang mampu memahaminya. Rekaman berupa dokumen elektronik dimiliki oleh masyarakat denga sadar ataupun tidak sadar yang merupakan hasil dari berbagai interaksi maupun transaksi elektronik yang sudah sangat lazim dilakukan dewasa ini. Rekaman elektronik yang merupakan dokumen elektronik ini memuat informasi elektronik yang juga telah diatur dan dijelaskan pada Pasal 1 Angka 1 Undang-Undang ITE merupakan satu atau sekumpulan data elektronik, termasuk tetapi tidak terbatas pada tulisan, suara, gambar, peta,

\footnotetext{
${ }^{10}$ Darwin Prinst, Hukum Acara Pidana Dalam Praktik (Djambatan 1998).[52].

11 Eddy O.S. Hiariej, Teori \& Hukum Pembuktian (Erlangga 2012).[52].
} 
rancangan, foto, electronic data interchange (EDI), surat elektronik (electronic mail), telegram, teleks, telecopy atau sejenisnya, huruf, tanda, angka, Kode Akses, simbol, atau perforasi yang telah diolah yang memiliki arti atau dapat dipahami oleh orang yang mampu memahaminya.

Informasi Elektronik dan/atau Dokumen Elektronik dinyatakan sah apabila menggunakan Sistem Elektronik yang memenuhi persyaratan minimum sebagai berikut (pasal 5 ayat (3) jo. Pasal 6 UU No. 11/2008):

a. dapat menampilkan kembali Informasi Elektronik dan/atau Dokumen Elektronik secara utuh sesuai dengan masa retensi yang ditetapkan dengan Peraturan Perundang-undangan;

b. dapat melindungi ketersediaan, keutuhan, keotentikan, kerahasiaan, dan keteraksesan Informasi Elektronik dalam Penyelenggaraan Sistem Elektronik tersebut;

c. dapat beroperasi sesuai dengan prosedur atau petunjuk dalam Penyelenggaraan Sistem Elektronik tersebut;

d. dilengkapi dengan prosedur atau petunjuk yang diumumkan dengan bahasa, informasi, atau simbol yang dapat dipahami oleh pihak yang bersangkutan dengan Penyelenggaraan Sistem Elektronik tersebut; dan

e. memiliki mekanisme yang berkelanjutan untuk menjaga kebaruan, kejelasan, dan kebertanggungjawaban prosedur atau petunjuk.

\section{b. Social Media}

Media sosial berbasis elektronik yang secara umum dan internaional disebut dengan Social Media merupakan suatu aplikasi atau sarana digital yang dapat dipergunakan melalui media ataupun sistem elektronik. Social Media merupakan sarana virtual yang dipergunakan masyarakat yang pada umumnya untuk berinteraki, bersosialisasi hingga dapat melakukan suatu perikatan dan perjanjian. Dijelaskan dalam McGraw Hill Dictionary, Media sosial adalah sarana yang digunakan oleh orang-orang untuk berinteraksi satu sama lain dengan cara menciptakan, berbagi, serta bertukar informasi dan gagasan dalam sebuah jaringan dan komunitas virtual. ${ }^{12}$

Contoh beberapa Social Media adalah: email, facebook, twitter, youtube, intagram, whatsapp, line dan masih banyak lagi jenis dan produk aplikasi Social Media yang dengan mudah dapat diakses dan dipergunakan oleh masyarakat dari

12 Nurudin, Media Sosial Baru dan Munculnya Revolusi Baru Proses Komunikasi (Buku Litera 2012).[3]. 
berbagai kalangan usia. Social Media menjadi sarana komunikasi yang saat ini sangat penting dan paling sering dipergunakan jauh meninggalkan sarana SMS (Short Massage Service) yang konvensional.

\section{c. Personal Chat}

Chatting secara umum adalah aktivitas berkomunikasi yang dilakukan oleh dua orang atau lebih dengan memanfaatkan aplikasi personal chat dan jaringan internet. Aplikasi personal chat saat ini sudah sangat maju. Tidak hanya mengirim pesan teks saja, aktivitas chatting sekarang ini juga bisa mengirimkan emoticon, pesan suara, bahkan video. Chatting adalah suatu pesan instan dalam teknologi jaringan komputer untuk mengirimkan informasi ke pengguna lain yang terhubung melalui koneksi internet. ${ }^{13}$ Personal Chat merupakan fitur chatting ataupun sarana wajib yang ditawarkan oleh setiap social media. Personal Chat yang diterjemahkan kedalam bahasa Indonesia merupakan percakapan pribadi menjadi sarana komunikasi utama pada semua aplikasi social media. Personal Chat dapat dipergunakan tanpa menggunakan biaya pulsa maupun pembayaran lainya, sarana ini dapat diakses melalui dukungan internet kepada perangkat elektronik untuk dapat digunakan atau diakses dengan tanpa batas dan sangat praktis. SMS ataupun sarana telepon konvensional sudah sangat jauh ditinggalkan dikarenakan pada Personal Chat juga dapat mengirimkan tidak hanya pesan berupa karakter huruf maupun angka akan tetapi juga dapat melampirkan foto, video maupun format digital lainnya yang dengan sangat maksimal mendukung komunikasi maupun interaksi bagi setiap penggunanya.

Secara umum, Chatting memiliki beberapa fungsi, diantaranya:

a. Sebagai sarana berkomunikasi yang paling mudah, cepat dan efisien;

b. Sebagai sarana untuk saling berkonsultasi lebih mudah;

c. Alat untuk menjalin hubungan dengan orang lain;

d. Bisa digunakan untuk berkumpul pada suatu grup atau multiple chat. ${ }^{14}$

${ }^{13}$ Nasrullah Rulli, Media sosial: Prespektif Komunikasi, Budaya dan Sosioteknologi (Simbiosa Rekatama Media 2015).[4].

${ }^{14}$ Ibid.[23]. 
Berikut ini beberapa manfaat adanya fitur chatting untuk mengembangkan bisnis: 1. Sarana Komunikasi

Sudah disinggung dari pengertian chatting diatas bahwa tujuannya adalah untuk memudahkan cara berkomunikasi jarak jauh. Dengan adanya fitur chatting saat ini akan semakin memudahkan sistem koordinasi dalam sebuah perusahaan.

Untuk menyampaikan informasi yang terkesan penting dan segera maka bisa memanfaatkan fitur chatting. Dengan chatting juga bisa menyampaikan pesan atau informasi langsung ke beberapa orang seperti pada fitur grup chatting. Tentu hal ini sangat berdampak positif terhadap bisnis.

2. Sumber Informasi Paling Cepat

Chatting diklaim sebagai perantara penyampaian informasi pealing cepat. Untuk bertukar informasi, Anda tidak perlu menemui orang yang bersangkutan atau menghabiskan pulsa dengan menelpon karena bisa dilakukan hanya dengan Chatting. 3. Meningkatkan Efisien waktu

Memang tidak bisa dipungkiri karena adanya fitur chatting saat ini sangat mempermudah pekerjaan kita. Untuk membuat janji atau pertemuan mendadak tidak harus menggunakan surat secara resmi, karena saat ini sudah banyak yang melakukan undangan via chatting. Sehingga dengan chatting dapat menghemat waktu yang diperlukan untuk menyebar undangan.

4. Media Untuk Berkomunikasi dengan Pelanggan

Chatting tidak hanya memudahkan komunikasi antar anggota perusahaan saja, namun juga bertujuan untuk memudahkan interaksi dengan pelanggan. Dengan chatting maka Anda akan lebih mudah terhubung dengan pelanggan misalnya untuk pemesanan produk, komplain atau lainnya.

\section{Sebagai Sarana Pemasaran}

Di jaman yang serba gadget ini tentu Anda tidak perlu lagi mengeluarkan budget lebih untuk pemasaran atau promosi dengan mencetak brosur. Anda cukup membuat bahan promosi dalam bentuk digital dan kemudian melakukan penyebaran via chatting. Cara promosi seperti ini sudah dianggap "lumrah" dikalangan pebisnis, terutama yang berbisnis secara online. 
Sekarang ini ada banyak sekali aplikasi chatting yang bisa digunakan untuk berkomunikasi dengan orang lain. Pada umumnya aplikasi chatting ini dapat digunakan secara gratis. Beberapa aplikasi chatting yang sering digunakan saat ini adalah: WhatssApp, Blackberry Messenger, Facebook Messenger, Line, WeChat, Kakao Talk, Google Hangout, Facebook Messenger dan lain-lain. ${ }^{15}$

\section{d. Alat Bukti}

KUHAP juga tidak memberikan pengertian mengenai alat bukti. Akan tetapi pada Pasal 183 KUHAP disebutkan "Hakim tidak boleh menjatuhkan pidana kepada seorang kecuali apabila dengan sekurang-kurangnya dua alat bukti yang sah ia memperoleh keyakinan bahwa suatu tindak pidana benar-benar terjadi dan bahwa terdakwalah yang bersalah melakukannya". Rumusan pasal ini memberikan kita garis hukum, bahwa:

a) Alat bukti diperoleh dari hasil pemeriksaan di sidang pengadilan;

b) Hakim mengambil putusan berdasarkan keyakinannya;

c) Keyakinan hakim diperoleh dari minimal dua alat bukti yang sah.

Didik Endro Purwoleksono, menulis dalam Modul Kuliah Kapita Selekta Hukum Pidana, Modul Kuliah khusus untuk mahasiswa Magister Hukum Program Pascasarjana Universitas Airlangga Surabaya, 2012, halaman 7, dampak positif di sini yaitu, sesuai dengan ciri-ciri khas masyarakat "abad millenium" sekarang ini, yaitu:

1. Ditandai dengan era "cyber" (dunia maya/dunia mayantara/siber);

2. Masyarakat informasi;

3. Tidak ada batasan teritorial (borderless), artinya yang ada adalah batasan "teknologi";

4. Yang jauh sekarang menjadi dekat;

5. Paper-based menjadi paperless;

6. Informasi begitu cepat menyebar;

7. Perdagangan via elektronik.

Lebih lanjut ditulis oleh Didik Endro Purwoleksono, dalam modul yang sama, "Di sisi yang lain, sebagaimana dijelaskan dalam UU ITE di atas, sekarang bermunculan tindak pidana dengan menggunakan sarana teknologi yang cukup

${ }^{15}$ Ibid.[29]. 
canggih atau dikenal dengan cyber crime atau kejahatan siber". Ciri khas cyber crime atau kejahatan siber di sini yaitu:

1. Dilakukan oleh orang pintar;

2. Menggunakan teknik yang canggih dan rumit untuk dapat dibuktikan jika hanya dengan pasal-pasal pidana konvensional (KUHP);

3. Berdimensi lebih luas dari pada tindak pidana biasa.

UU ITE telah mengantisipai baik kejahatan siber maupun kejahatan yang dilakukan dengan sarana informasi dan teknologi, dengan diaturnya ketentuan pidana sebagaimana diatur dalam BAB XI, Pasal 45 sampai dengan Pasal 52. Di sisi lain, alat bukti yang diatur oleh UU ITE, juga telah memberikan pengaturan tentang alat bukti elektronik. Tepatnya diatur dalam Pasal 5 UU ITE yang berbunyi:

1) Informasi Elektronik dan/atau Dokumen Elektronik dan/atau hasil cetakannya merupakan alat bukti yang sah.

2) Informasi Elektronik dan/atau Dokumen Elektronik dan/atau hasil cetaknya sebagaimana dimaksud pada ayat (1) merupakan perluasan dari alat bukti yang sah sesuai dengan Hukum Acara yang berlaku di Indonesia. ${ }^{16}$

Berdasarkan Pasal 184 KUHAP, disebutkan:

Alat Bukti yang sah ialah:
a. Keterangan saksi;
b. Keterangan ahli;
c. Surat;
d. Petunjuk;
e. Keterangan terdakwa. ${ }^{17}$

Keberadaan alat bukti elektronik ini, tidak dapat dilepaskan dengan perkembangan perundang-undangan terkait dengan pembuktian perkara pidana seiring dengan perkembangan teknologi. Bila kita bandingkan dengan sistem Common Law seperti di Amerika Serikat, alat-alat bukti tersebut sangat berbeda. Dalam Criminal Procedure Law Amerika Serikat, yang disebut forms of

16 Purwoleksono, Didik Endro, Hukum Acara Pidana (Airlangga University Press 2015). [120-121].

17 Ibid.[113]. 
evidence atau alat bukti adalah: real evidence, documentary evidence, testimonial evidence dan judicial notice. Dalam sistem Common Law ini, real evidence (barang bukti) merupakan alat bukti yang paling bernilai. Padahal real evidence atau barang bukti ini tidak termasuk alat bukti menurut hukum acara pidana kita.

Bila memperhatikan keterangan di atas, tidak terlihat adanya hubungan antara barang buktidengan alatbukti. Pasal 183 KUHAP mengatur bahwa untuk menentukan pidana kepada terdakwa, kesalahannya harus terbukti dengan sekurang-kurangnya dua alat bukti yang sah; dan atas keterbuktian dengan sekurang-kurangnya dua alat bukti yang sah tersebut, hakim memperoleh keyakinan bahwa tindak pidana benarbenar terjadi dan bahwa terdakwalah yang bersalah melakukannya.

\section{Syarat Otentifikasi dan Kekuatan Pembuktian Alat Bukti Rekaman Elektronik Personal Chat pada Social Media Dalam Acara Pidana}

Dalam pembahasan yang telah dibahas mengenai teori-teori, doktrin-doktrin serta peraturan perundang-undangan yang berlaku di Indonesia, penulis berusaha untuk merumuskan dan menyimpulkan mengenai syarat otentifikasi suatu informasi elektronik dan/atau dokumen elektronik terkait serta mengenai kekuatan pembuktian alat bukti informasi elektronik dan/atau dokumen elektronik ini dalam perkara pidana.

Suatu informasi elektronik dan/atau dokumen elektronik yang dalam hal ini mengkhusus pada rekaman personal chat pada social media dapat menjadi alat bukti yang sah dipersidangan haruslah sudah bersertifikasi, baik mengenai subyek maupun sistemnya. Hal ini juga mendasarkan kepada Pasal 7 UU ITE yang disebut sebagai berikut:

"Setiap org yang menyatakan hak, memperkuat hak yang telah ada, atau menolak hak orang lain berdasarkan adanya informasi elektronik dan/atau dokumen elektronik harus memastikan bahwa informasi elektronik dan/atau dokumen elektronik yang ada padanya berasal dari sistem elektronik yang memenuhi syarat berdasarkan peraturan perundang-undangan".

Untuk menjamin otentifikasi suatu informasi elektronik dan/atau dokumen elektronik, maka haruslah juga memenuhi syarat yang telah diatur pada Bab IV Pasal 13 sampai dengan Pasal 16 UU ITE yang menjelaskan mengenai persyaratan- 
persyaratan suatu alat bukti berupa informasi elektronik dan/atau dokumen elektronik yang termasuk sebagai dokumen autentik haruslah dibuat oleh penyelenggara sertifikat elektronik dan sistem elektronik. Berbagai social media yang ada saat ini di Indonesia telah tumbuh dan berkembang seiring dengan penggunaan segala fitur-fitur berbasis online oleh masyarakat luas. Sarana komunikasi dalam hal ini personal chat sudah cukup sering dijadikan sebagai alat bukti informasi elektronik dan/atau dokumen elektronik dalam permasalahan hukum di Indonesia.

Akan tetapi suatu personal chat dapat dijadikan alat bukti yang sah dimuka pengadilan haruslah dilakukan uji otentifikasi dan verifikasi terlebih dahulu. Dengan tahapan suatu personal chat pada social media tersebut dapat diperlihatkan melalui perangkat elektronik dan hasil cetaknya sebagai suatu informasi elektronik dan/atau dokumen elektronik. Kemudian tahapan selanjutnya para subyek-subyek yang berinteraksi melalui suatu personal chat pada social media tersebut haruslah terverifikasi dengan cara terkoneksi dengan alamat email yang sesuai dan juga terkoneksi dengan nomor telepon yang wajib telah terdaftar sesuai dengan identitas asli para pihak pemilik akun. Selanjutnya tentu harus diperkuat oleh keterangan ahli dimuka persidangan dalam hal ini mengkhusus kepada ahli digital forensik agar memberikan suatu keyakinan kepada hakim bahwa suatu alat bukti personal chat pada social media tersebut ialah memenuhi syarat-syarat otentifikasi dan verifikasi serta benar-benar sah dapat dijadikan sebagai alat bukti dalam suatu persidangan.

Sedangkan mengenai kekuatan pembuktiannya dalam suatu perkara pidana haruslah melihat dari social media yang dipergunakan aleh para pihak yang berperkara didalamnya. Hal tersebut dikarenakan, penulis telah meneliti beberapa social media tidak secara ketat untuk memberlakukan autehnticity (otentisitas) kepada para pengguna layanannya. Pengaruh otentisitas ini sangatlah besar terhadap layanan serta penggunaan personal chat pada social media tersebut. Tanpa adanya otentisitas yang ketat yang diberlakukan oleh pihak penyedia jasa layanan social media ini maka setiap pihak dapa menyalahgunakan kesempatan ini untuk membuat akun palsu atau tidak sesuai dengan identitas asli orang tersebut. 
Namun demikian, beberapa social media lain juga sudah menerapkan otentisitas yang cukup ketat dengan mengkoneksikasikan akun social media tersebut dengan akun utama yahoo, facebook, ataupun juga wajib terkoneksi melalui provider selular dari setiap pengguna jasa layanannya. Oleh karenanya kekuatan pembuktian dari suatu personal chat pada social media tersebut juga bergantung pada platform atau aplikasi social media yang dipergunakan guna dapat dijadikan alat bukti elektronik yang sah dimuka pengadilan. Berikut penulis melakukan komparasi dari beberapa situr atau aplikasi social media yang populer digunakan di Indonesia.

\section{Komparasi Personal Chat Pada Social Media Sebagai Alat Bukti}

\section{A. Yahoo! Massenger}

Yahoo! merupakan salah satu social media yang utama dari segala platform basis aplikasi online lainnya. Yahoo! Inc. didirikan oleh Jerry Yang dan David Filo pada bulan Januari 1994 dan dibentuk 2 Maret 1995. Layanan Yahoo! Massenger diawal jaman milenia sangatlah populer. Merupakan pelopor personal chat pertama berbasis online pada social media. Otentisitas dari fitur personal chat pada Yahoo! Massenger sudah sangat baik, akan tetapi perlu juga dicermati bilamana pada suatu kasus hukum di Indonesia mempergunakan alat bukti rekaman elektronik personal chat pada Yahoo! Massenger hendaknya melihat dari tanggal akses yang dipergunakan oleh para subjek didalamnya. Hal tersebut sangatlah penting dikarenakan per-17 Juli 2018 Yahoo! Massenger secara resmi menutup basis platformnya tersebut. Sehingga dapat disimpulkan alat bukti rekama elektronik personal chat pada Yahoo! Massenger setelah tanggal tersebut tidak dapat diakui atau tidak lulus otentifikasi dan tidak sah sebagai alat bukti rekaman elektronik dimuka pengadilan.

\section{B. Facebook Messenger}

Facebook merupakan salah satu aplikasi yang besar dan sangat terkenal yang berpusat di Menlo Park, California, Amerika Serikat yang dilaunching pada bulan Februari 2004. Pengguna aplikasi ini harus mendaftar terlebih dahulu sebelum dapat menggunakan situs dan layanan yang terdapat di dalamnya. Kemudian, pengguna 
dapat membuat profil pribadi, menambahkan akun pengguna lain sebagai teman, dan bertukar pesan. Selain itu juga, pengguna dapat bergabung dengan grup pengguna lain dengan hobi serta ketertarikan yang sama, diurutkan berdasarkan tempat kerja, sekolah atau perguruan tinggi, atau ciri khas lainnya, dan mengelompokkan temanteman mereka ke dalam daftar seperti "Rekan Kerja" atau "Teman Dekat".

Facebook Messenger menjadi fitur personal chat yang juga cukup populer dikalangan pengguna setia facebook. Facebook juga sudah sangat baik dalam melakukan otentisitas kepada setiap pengguna layanan social medianya. Dengan wajib mengkoneksikan alamat yahoo serta provider selular setiap penggunanya sudahlah cukup untuk memberikan perlindungan terhadap otentifikasi bagi para pengguna layanannya. Mengenai penggunaan rekaman elektronik personal chat pada fitur facebok yaitu facebook messenger tentunya haruslah dilakukan pemverifikasian mengenai kesesuaiian antara para pihak yang berinteraksi didalamnya dengan terlebih dahulu melihat keterangan detail profile pengguna akun tersebut di halaman atau beranda profilenya. Hal tersebut sudahlah cukup dijadikan sebagai pegangan bahwa hasil rekaman elektronik personal chat pada facebook messenger ini dapat dijadikan alat bukti yang sah dimuka pengadilan.

\section{WhatsApp}

WhatsApp Messenger adalah aplikasi pesan yang sangat populer dikalangan masyarakat Indonesia. WhatsApp Messenger merupakan salah satu aplikasi yang memungkinkan kita bertukar pesan tanpa biaya SMS, karena WhatsApp mempergunakan paket data internet berbasis online seperti aplikasi online lain pada umumnya. Dengan mempergunakan whatsApp, kita dapat mengobrolan secara online, berbagi file/data, bertukar foto dan akses dan fitur-fitur lainnya. ${ }^{18}$

Pada WhatsApp untuk menambahkan teman pada kontak pertemanan, hanya memerlukan nomor handphone teman anda. Kepraktisannya, anda tidak perlu lagi menambahkan kontak teman pada aplikasi whatsApp tersebut. Cukup dengan mengisi daftar telephone anda dengan teman anda, kemudian dengan

\footnotetext{
${ }^{18}$ Hartanto, AAT, Panduan Aplikasi Smartphone (Gramedia Pustaka Utama 2010).[100].
} 
mengsinkronisasi atau menekan tombol refresh pada pilihan saat berada di daftar pertemanan anda. Bila teman anda telah terdaftar menggunakan nomor handphone tersebut, maka whatsApp akan secara otomatis untuk mencarinya dan menampilkan teman anda langsung pada daftar panggilan anda.

Seperti penjelasan mengenai whatsapp diatas pengkoneksian antara akun whatsapp dengan nomor telepon atau suatu provider selular pengguna akaunnya sudah sangat mudah atau otomatis. Namun perlu diingat bahwa platform atau aplikasi whatsapp ini tidak terkoneksi dengan akun yahoo dan hanya berbasis pada nomor telepon pengguna. Mengenai otentisitas pengguna akunnyapun sangat lemah dikarenakan kepraktisannya tersebut. Sehingga sangatlah rawan untuk disalahgunakan oleh pihak-pihak yang dengan niat untuk melakukan suatu tipu muslihat atau suatu tindakan kejahatan lainnya. Terkait dengan penggunaan rekaman elektronik whatsapp sebagai alat bukti dimuka pengadilan haruslah dilakukan pengujian alat bukti terlebih dahulu dalam proses pembuktiannya. Penting untuk melakukan otentisitas dan otentifikasi pengguna akun tersebut dengan memverifikasi dengan nomor telepon atau provider selular yang dipergunakan dari para pihak sehingga ditemukan kesesuaian yang menunjukan bahwa rekaman elektronik personal chat whatsapp itu memang alat bukti yang otentik dan sah sebagai alat bukti di pengadilan.

\section{LINE}

LINE merupakan sebuah aplikasi yang juga dapat mengirimkan pesan secara online pada smartphone, tablet, maupun komputer. Pada aplikasi LINE ini kita dapat melakukan kegiatan seperti mengirimkan pesan teks, mengirim foto maupun gambar, video dan juga pesan suara. LINE diciptakan oleh perusahaan NHN Corporation di Jepang. LINE pertama kali diluncurkan pada Juni 2011. LINE dapat diaplikasikan pada berbagai platform seperti ios, android maupun os windows serta perangkat sistem komputer lainnya. Serupa juga dengan aplikasi berbasis online lainnya LINE menggunakan nomor telepon sebagai acuan identitas penggunanya untuk mempermudah orang untuk mengundang anda.

Mengenai otentisitas akun pengguna LINE sudah cukup baik dengan terkoneksikan oleh alamat email dan nomor telepon ataupun provider selular 
penggunanya. Akan tetapi tanpa melakukan authorization tersebut juga pengguna tetap dapat membuat akun baru dan sudah dapat untuk mempergunakan layanan personal chat pada basis aplikasi LINE ini. Oleh karenanya penting untuk dicermati bagi setiap pengguna akun memiliki identity user atau ID yang berbeda-beda, inilah fitur keamanan yang dapat dipergunakan untuk memastikan bahwa para pengguna layanan personal chat pada aplikasi LINE ini memanglah jelas dan menjamin otentisitasnya. Mengenai rekaman elektronik personal chat pada aplikasi LINE yang dijadikan sebagai alat bukti tidaklah terlepas dari melakukan otentifikasi akun tersebut, bila sudah sesuai dan memang dibenarkan bahwa akun tersebut merupakan akun yang otentik sesuai dengan para pihak barulah dapat dikatakan atau dijadikan alat bukti rekaman elektronik yang sah dimuka pengadilan.

\section{E. Direct Message Twitter}

Twitter merupakan salah satu aplikasi berbasis online yang memungkinkan penggunanya untuk mengunggah dan membaca pesan berbasis teks berjumlah 140 karakter akan tetapi pada tanggal 07 November 2017 bertambah hingga 280 karakter yang lebih dikenal dengan sebutan kicauan(tweet). Twitter berdiri pada Maret 2006 oleh pendirinya Jack Dorsey dan diluncurkan pada bulan Juli. Penggunaan twitter sedikit berbeda dari pada social media lainnya yang memang berbasis pada komunikasi dengan fitur utama personal chat, namun demikian pengguna twitter yang mencakup semua belahan dunia menjadikan twitter sangat penting untuk dibahas. Dalam aplikasi twitter kita juga dapat mengirimkan pesan personal kepada pengguna akun lain melalui fitur direct message. Bila mana terjadi permasalahan hukum yang kemudian menjadikan hasil dari direct message ini sebagai alat bukti maka haruslah dilakukan otentifikasi terhadap akun para pihak sehingga dapat menunjukkan otentisitas dari para pengguna akun twitter tersebut. Pada setiap akun pengguna twitter dipergunakan fitur identity user atau ID yang berbeda-beda dan menunjukkan identitas yang berbeda-beda pula pada setiap pengguna akun. Oleh karenanya suatu direct message pada aplikasi twitter ini dapat dijadikan suatu alat bukti rekaman elektronik personal chat yang sah bila telah memenuhi otentifikasi dari para pihak sehingga dapat menunjukkan otentisitas dari para pemilik akun twitter tersebut. 


\section{F. Direct Message Instagram}

Instagram merupakan sebuah aplikasi berbasis online untuk mengunggah foto maupun video yang memungkinkan pengguna lainnya untuk melihat dan menyukai serta mengomentari unggahannya tersebut. Pada Instagram juga terdapat fitur mengirimkan pean secara personal yang disebut direct message. Dengan fitur tersebut kita dapat bertukar pesan dan mengobrol secara pribadi tanpa harus bertukar komentar pada fitur garis waktu.

Hampir serupa dengan aplikasi twitter yang bukan mengkusus utama dalam social media berbasis komunikasi, yang membedakannya adalah instagram memiliki poin utama pada mengunggah file foto maupun video pada social media miliknya. Kemiripan atau cenderung dapat dikatakan kesamaan dalam kedua aplikasi ini adalah fitur direct message yang ada pada intagram. Selain itu juga penggunaan identty User atau ID juga dipergunakan intagram untuk menunjukkan karakteristik dan juga keamanan otentisitas bagi para pengguna layanan jasa aplikasinya. Serupa mengenai fitur-fitur yang ditawarkan begitu juga mengenai pembahasan direct message pada aplikasi instagram ini. Bila pada suatu perkara pidana direct message pada aplikasi instagram menjadi suatu alat bukti rekaman elektronik personal chat maka harus dilakukan otentifikasi pada para pengguna akun terebut. Poin penting yang dapat disesuaikan sebagai patokan utamanya ialah pada identity User atau ID yang digunakan para pihak. Karena setiap akun pengguna instagram ini memiliki ID yang berbeda-beda yang tentunya dapat dijadikan sebagai syarat otentifikasi dipengadilan agar dapat menjadikan suatu rekaman elektronik direct message pada aplikasi instagram tersebut sebagai alat bukti yang sah dimuka pengadilan.

\section{Kesimpulan}

Sesuai yang telah disebut pada Pasal 5 ayat Undang-Undang No. 11 Tahun 2008 tentang Informasi dan Transaksi Elektronik Informasi Elektronik dan/atau Dokumen Elektronik dan/atau hasil cetaknya merupakan alat bukti hukum yang sah. Namun tidaklah jelas diterangkan mengenai personal chat pada social media secara lebih mendetail, oleh karenanya dibutuhkan regulasi baru yang dibuat oleh 
pemerintah sehingga mampu mangakomodir ketentuan-ketentuan yang kedepannya dirasa mampu menjadi celah-celah hukum bagi para penyalahguna keadaan sehingga dapat dijadikan media ataupun fasilitas sebagai suatu sarana dalam menjalankan dan melakukan aksi kejahatan di Indonesia.

Mengenai syarat formil pada Pasal 5 ayat (4) UU ITE, yaitu bahwa Informasi atau Dokumen Elektronik bukanlah dokumen atau surat yang menurut perundangundangan harus dalam bentuk tertulis. Sedangkan syarat materil diatur dalam Pasal 6, Pasal 15, dan Pasal 16 UU ITE, yang pada intinya Informasi dan Dokumen Elektronik harus dapat dijamin keotentikannya, keutuhannya, dan ketersediaanya. Untuk menjamin terpenuhinya persyaratan materil yang dimaksud, dalam banyak hal dibutuhkan digital forensik.

Untuk menjamin otentifikasi suatu informasi elektronik dan/atau dokumen elektronik, maka haruslah juga memenuhi syarat yang telah diatur pada Bab IV Pasal 13 sampai dengan Pasal 16 UU ITE yang menjelaskan mengenai persyaratanpersyaratan suatu alat bukti berupa informasi elektronik dan/atau dokumen elektronik yang termasuk sebagai dokumen autentik haruslah dibuat oleh penyelenggara sertifikat elektronik dan sistem elektronik. Berbagai social media yang ada saat ini di Indonesia telah tumbuh dan berkembang seiring dengan penggunaan segala fitur-fitur berbasis online oleh masyarakat luas. Sarana komunikasi dalam hal ini personal chat sudah cukup sering dijadikan sebagai alat bukti informasi elektronik serta dokumen elektronik dalam permasalahan hukum di Indonesia.

Akan tetapi suatu personal chat dapat dijadikan alat bukti yang sah dimuka pengadilan haruslah dilakukan uji otentifikasi dan verifikasi terlebih dahulu. Dengan tahapan suatu personal chat pada social media tersebut dapat diperlihatkan melalui perangkat elektronik beserta hasil cetaknya sebagai suatu informasi elektronik serta dokumen elektronik. Kemudian tahapan selanjutnya para subyek-subyek yang berinteraksi melalui suatu personal chat pada social media tersebut haruslah terverifikasi dengan cara terkoneksi dengan alamat email yang sesuai dan juga terkoneksi dengan nomor telepon yang wajib telah terdaftar sesuai dengan identitas asli para pihak pemilik akun. Selanjutnya tentu harus diperkuat oleh keterangan ahli 
dimuka persidangan dalam hal ini mengkhusus kepada ahli digital forensik agar memberikan suatu keyakinan kepada hakim bahwa suatu alat bukti personal chat pada social media tersebut ialah memenuhi syarat-syarat otentifikasi dan verifikasi serta benar-benar sah dapat dijadikan sebagai alat bukti dalam suatu persidangan.

Sedangkan mengenai kekuatan pembuktiannya dalam suatu perkara pidana haruslah melihat dari social media yang dipergunakan aleh para pihak yang berperkara didalamnya. Hal tersebut dikarenakan, penulis telah meneliti beberapa social media tidak secara ketat untuk memberlakukan autehnticity (otentisitas) kepada para pengguna layanannya. Pengaruh otentisitas ini sangatlah besar terhadap layanan serta penggunaan personal chat pada social media tersebut. Tanpa adanya otentisitas yang ketat yang diberlakukan oleh pihak penyedia jasa layanan social media ini maka setiap pihak dapa menyalahgunakan kesempatan ini untuk membuat akun palsu atau tidak sesuai dengan identitas asli orang tersebut.

\section{Daftar Bacaan}

Adhami, Chazawi, Hukum Pembuktian Tindak Pidana Korupsi (Alumni 2008).

---------, Pelajaran Hukum Pidana Bagian 1 (Rajawali Pers 2008).

----------, Pelajaran Hukum Pidana Bagian 2 (Rajawali Pers 2011).

---------, Pelajaran Hukum Pidana Bagian 3 (Rajawali Pers 2011).

Andi, Hamzah, Hukum Acara Pidana Indonesia (Sinar Grafika 2014).

Alfitra, Hukum Pembuktian dalam beracara Pidana, Perdata dan Korupsi di Indonesia (Raih Asa Sukses 2011).

Hendar, Soetarna, Hukum Pembuktian dalam Acara Pidana (Alumni 2011).

Martin Basiang, The Contemporary Law Dictionary (Gramedia Pustaka Utama 2016).

M. Yahya, Harahap, Pembahasan Permasalahan dan Penerapan KUHAP: Pemeriksaan Sidang Pengadilan, Banding, Kasasi, dan Peninjauan Kembali: Edisi Kedua (Sinar Grafika 2005). 
Muladi \& Barda, Nawawie Arief, Teori - teori dan Kebijakan Pidana (Alumni 2010).

Nasrullah Rulli, Media sosial: Prespektif Komunikasi, Budaya dan Sosioteknologi (Simbiosa Rekatama Media 2015).

Nurudin, Media Sosial Baru dan Munculnya Revolusi Baru Proses Komunikasi (Buku Litera 2012).

Peter Mahmud Marzuki, Penelitian Hukum Edisi Revisi (Kencana Prenada Group 2016).

Purwoleksono, Didik Endro, Hukum Pidana, (Airlangga University Press 2014).

--------, Hukum Acara Pidana, (Airlangga University Press 2015).

R. Subekti, Hukum Pembuktian (Balai Pustaka 2015).

Rusli, Muhammad, Hukum Acara Pidana Kontemporer (Citra Aditya Bakti 2007).

Shiefti Dyah Alyusi, Media Social, Interaksi, Identitas dan Modal Sosial (Prenada Media 2016).

Sukamaaji, Anjik dan Rianto, Jaringan Komputer: Konsep Dasar Pengembangan Jaringan \& Keamanan Jaringan (Subnet, VLSM, Routing, DES, PGP, \& Firewall) (Andi Offset 2008).

Siswanto, Sunarso, Hukum Informasi dan Transaksi Elektronik (Rineka Cipta 2009).

Tolib, Efendi, Dasar-Dasar Hukum Acara Pidana; Perkembangan Dan Pembaharuanya di Indonesia (Setara Press 2014).

Oetomo, Budi Sutedjo Dharma, Konsep dan Perancangan Jaringan Komputer (Andi Offset 2003).

Wardhana, Lingga dan Makodian, Nuraksa, Teknologi Wireless Communication Dan Wireless (Andi Publisher 2010).

\section{Jurnal}

Aditya Waisnawa, 'Kebijakan Formulatif Pengaturan Cyberbullying Sebagai Salah Satu Bentuk Tindak Pidana Cybercrime Di Indonesia' (2017) Jurnal Magister Hukum Udayana (Udayana Master Law Journal).6(4). 
Angga Juniarta, 'Legalitas Rekaman Circuit Closed Television (CCTV) Dalam Proses Pembuktian di Persidangan' (2018) Jurnal Magister Hukum Udayana (Udayana Master Law Journal).7(1).

Bastianto Nugroho, 'Peranan Alat Bukti Dalam Perkara Pidana Dalam Putusan Hakim Menurut KUHAP' (2017) Yuridika: Universitas Airlangga Surabaya.

Erma Lisnawati, 'Keabsahan Alat Bukti Elektronik Pasca Putusan Mahkamah Konstitusi No.20 / PUU-XVI / 2016 Dalam Prespektif Criminal Justice System' (2016) Jurnal Magister Hukum Udayana (Udayana Master Law Journal).5(4).

HOW TO CITE: I Putu Krisna Adhi, 'Rekaman Elekronik Personal Chat Pada Social Media Sebagai Alat Bukti' (2018) Vol. 1 No. 3 Media Iuris. 